\title{
Aboveground Biomass Stockpile and Carbon Sequestration Potential of Albizia saman in Chennai Metropolitan City, India
}

\author{
Muthulingam Udayakumar, ", Ammaiyappan Selvam ${ }^{1}$, Thangavel Sekar ${ }^{2}$ \\ ${ }^{1}$ Department of Plant Science, Manonmaniam Sundaranar University, Tirunelveli, Tamil Nadu, India \\ ${ }^{2}$ Department of Botany, Pachaiyappa's College, Chennai, Tamil Nadu, India
}

\section{Email address:}

udayakumar@msuniv.ac.in (M. Udayakumar)

${ }^{*}$ Corresponding author

\section{To cite this article:}

Muthulingam Udayakumar, Ammaiyappan Selvam, Thangavel Sekar. Aboveground Biomass Stockpile and Carbon Sequestration Potential of Albizia saman in Chennai Metropolitan City, India. Plant. Vol. 6, No. 3, 2018, pp. 60-66. doi: 10.11648/j.plant.20180603.12

Received: June 19, 2018; Accepted: September 29, 2018; Published: October 29, 2018

\begin{abstract}
Albizia saman (Jacquin) F. Mueller belongs to the family Fabaceae (sub family: Mimosoideae) is a native to Northern South America. Commonly known as rain tree and locally known as Thoongu-moonchi maram (Tamil). The species' introduced during Colonial period as an ornamental tree in Chennai metropolitan city (CMC). Though A. saman represent as a dominant tree species' in CMC, there are voids in baseline data such as density, biomass stockpile, and annual C sequestration potential hence this study was conducted to fill these voids. A total of 2522 individuals which cover $1672.14 \mathrm{~m}^{2}$ basal area $\left(\right.$ mean $=9.61 \pm 4.95 \mathrm{~m}^{2} \mathrm{ha}^{-1}$; range $=0-24.96 \mathrm{~m}^{2} \mathrm{ha}^{-1}$ ) was recorded from study plots. During study period $A$. saman stocked a sum of 6403.51 Mg aboveground biomass (AGB) (mean $=36.8 \pm 18.9 \mathrm{Mg} \mathrm{ha}^{-1}$; range $=0-95.4 \mathrm{Mg} \mathrm{ha}^{-1}$ ) and $3201.76 \mathrm{Mg} \mathrm{C}$ $\left(\right.$ mean $=18.9 \pm 9.45 \mathrm{Mg} \mathrm{ha}^{-1}$; range $\left.=0-47.7 \mathrm{Mg} \mathrm{ha}^{-1}\right)$. C storage of individual tree ranged from 3.74 to $4598.18 \mathrm{~kg}$ with a mean value of $1269.53 \pm 1082.25 \mathrm{~kg}$. On an average, each tree achieved $1.04 \pm 0.27 \mathrm{~cm}$ horizontal growth $\mathrm{yr}^{-1}$. In a year $A$. saman population sequestered $111.23 \mathrm{Mg}$ biomass in aboveground (in $174 \mathrm{ha}$ ). The mean C sequestration of study area was $319.62 \pm 184.0 \mathrm{~kg} \mathrm{ha}^{-1}$ year $^{-1}$. In total, the study area sequestered $55.62 \mathrm{Mg} \mathrm{C}$ year ${ }^{-1}$. Overall, in a year $A$. saman absorbed 204.13 $\mathrm{Mg} \mathrm{CO}_{2}$ for $\mathrm{C}$ sequestration in study area. $\mathrm{CO}_{2}$ absorption ranged from 385.46 to $3009.29 \mathrm{~kg} \mathrm{ha}^{-1} \mathrm{yr}^{-1}$. The monetary value of $\mathrm{C}$ storage and annual sequestration of $A$. saman is also investigated. Though introduced from tropical Northern South America A. saman provides a considerable ecosystem services to CMC through $\mathrm{C}$ storage and sequestration. This study estimated monetary values of just two ecosystem services of $A$. saman, study that concentrates on all ecosystem services is essential to assess total actual ecosystem service values.
\end{abstract}

Keywords: Ecosystem Service, Exotic Tree Species, Stem Horizontal Growth, Tamil Nadu, Tropical City

\section{Introduction}

Urban areas are home for about half of the global human population [1]. An estimation shows that urban human population will increase up to 5 billion by 2030 . Approximately, 1.2 million $\mathrm{km}^{2}$ area (three times larger compared to the year 2000) would come under cities in 2030, ultimately, this would lead to loss of biodiversity and forest cover around the world including India [2]. Thus, in-depth scientific studies are essential to understand the importance of urban forests and ecosystem services they provide. Tireless efforts and decades of continuous research work has advanced our understanding of urban forests and green spaces [3]. Urban forests and their biotic components play vital roles in reducing energy budgets of building and urban heat islands [4, 5], augmenting water and air quality [6], decreasing the impacts of flooding [7], improving human health and reducing sound pollution [8]. Among lifeforms, trees are important constituent of urban ecosystems. Besides, urban trees do array of ecosystem services including biomass and carbon storage [9].

Urban forests are either rich in native species [10] or introduced species [11]. McKinney [12] named the introduced species as urban exploiters, found extensively 
from urban areas around the world. Introduced trees can also provide considerable quantum of ecosystem services [13]. Albizia saman (Jacquin) F. Mueller belongs to the family Fabaceae (sub family: Mimosoideae) is a native to Northern South America. Commonly known as rain tree and monkey pod, locally known as Thoongu-moonchi maram (Tamil). Now extensively grows throughout the tropics. It reaches up to $25 \mathrm{~m}$ tall and $30 \mathrm{~m}$ crown diameter, highly suitable for large homesteads, parks, roadsides and school play grounds [14]. The tree has good qualities, grows well at sea level to $300 \mathrm{~m}$ amsl, adapts to a broad array of soil types and $\mathrm{pH}$ ranges, growth rate is relatively high $\left(2.5-5 \mathrm{ft} \mathrm{yr}^{-1}\right)$, produces fodder and timber, generates $1700-4200 \mathrm{~kg}$ biomass in 5 years [14]. Besides that the tree also has economic importance as fuel wood [15], food and fodder [16], timber [17], gum and resin [18], nitrogen fixer and green manure [19], and medicine [20, 21].

The species was introduced during Colonial period as an ornamental tree in Chennai metropolitan city (CMC) [22]. Now it grows extensively in parks, roadsides, playgrounds of academic institutions, and avenues in CMC [23]. The urban forest division of Chennai district prefers this tree for its fastgrowing nature, handsome dome-shaped crown and shade. Though A. saman represent as a dominant species in CMC there are voids in baseline data such as density, sequestered biomass, $\mathrm{C}$ stockpile and sequestration potential hence this study was conducted to fill these voids.

\section{Methods}

\subsection{Study Area}

Chennai Metropolitan city is 34th largest city in the world with the human population $\sim 5$ million [24]. CMC is one among the four mega-cities of the Indian subcontinent, and the capital city of Tamil Nadu state. The city is experiencing a tropical dissymmetric climate and receiving bulk of the rainfall during north-east monsoon (September-December). Mean temperature and rainfall were $30^{\circ} \mathrm{C}$ and $1300 \mathrm{~mm}$ [25]. East-side of the city is bounded with the Bay of Bengal and remaining three sides are bordered with Thiruvallur and Kanchipuram districts. CMC is endowed with rich plant diversity (1039 species) [24] which include both native as well as introduced species.

\subsection{Field Survey}

The entire geographical area of CMC $\left(174 \mathrm{~km}^{2}\right)$ was divided in to the regular rectangular grids $\left(1 \mathrm{~km}^{2} \times 1 \mathrm{~km}^{2}\right)$ by fishnet tool of ArcGIS software (version 9.3). The sample sites were selected randomly inside of the each grid. A total of 174 one-hectare sample plots were laid to record density and diameter at breast height (dbh) of Albizia saman $(>5 \mathrm{~cm}$ $\mathrm{dbh}$ ). Diameter of all trees $>5 \mathrm{~cm}$ dbh was measured at the height of $137 \mathrm{~cm}$ above the ground and recorded in field data sheet. In order to record DBH value for consecutive years, trees were tagged with consecutively numbered aluminium tags. Field survey was conducted during January-March on
2011 and 2012. Data on trees was recorded with the help of students of Botany departments across the Chennai city. Rainfall and temperature recorded in the year 2011 and 2012 were more or less equal to the mean rainfall and temperature of the study area, hence the study period represented Chennai's usual climatic and environmental conditions.

\subsection{Estimation of Aboveground Biomass}

A region-cum-species specific allometric formula developed by destructive sampling method was employed to estimate AGB of Albizia saman in study area [26, 27]. AGB $\mathrm{dry}=\exp (1.9724 * \mathrm{LN}(\mathrm{DBH})-1.0717)$; where, AGB ${ }_{\text {dry }}$ is aboveground dry biomass of tree $(\mathrm{kg})$; DBH is stem diameter at breast height $(\mathrm{cm})$; LN is natural logarithm; 1.9724 and 1.0717 are constants. The allometric formula developed with the destructively sampled healthy individuals of $A$. saman (DBH range 4.45 to $178.7 \mathrm{~cm}$ ). Due to hetero-scedasticity nature of field data, the error variance was not constant. The problem was dealt with the transformation of variables. But the de-transformed predicted values are biased [28]. To overcome those bias, the back transformed results from logarithmic unit was multiplied by a conversion factor $(\mathrm{CF}=$ 1.016) [29]. DBH of trees ranged from 5 to $176 \mathrm{~cm}$ in the present study. The coefficient of determination of allometric equation is high $\left(r^{2}\right)$ i. e. 0.98 . Standard error of the estimate is 0.76 .

\subsection{Assessment of Carbon Storage and Sequestration}

To get carbon storage values of trees aboveground biomass multiplied by 0.50 [30]. The annual increase of stem diameter and biomass sequestration of trees were calculated by the difference in estimates of $\mathrm{dbh}$ and biomass stockpile between year $x$ and $x+1$. Carbon storage and sequestration values were converted to $\mathrm{CO}_{2}$ equivalent by multiplying with 3.67 , the ratio of molecular weights of $\mathrm{CO}_{2}$ to $\mathrm{C}$ [31].

\subsection{Monetary Value of Ecosystem Services}

The money value of ecosystem services provided by $A$. saman, namely $\mathrm{C}$ storage and sequestration was calculated based on international $\mathrm{C}$ price. International price for one tonne $\mathrm{C}$ is $41 \mathrm{US \$}$ [32].

\section{Results}

\subsection{Tree Density and Basal Area}

A total of 2522 individuals $(>5 \mathrm{~cm} \mathrm{dbh}$ ) was recorded in 174 ha. Density of trees ranged from $0-30 \mathrm{ha}^{-1}$. The mean tree density of $A$. saman was $14.49 \pm 8.52 \mathrm{ha}^{-1}$. Likewise, the basal area of trees varied from $0-24.96 \mathrm{~m}^{2} \mathrm{ha}^{-1}$. The average basal area of $A$. saman was $9.61 \pm 4.95 \mathrm{~m}^{2} \mathrm{ha}^{-1}$. Few sample plots completely fell on water bodies where density, basal area and $\mathrm{AGB}$ were recorded as ' 0 '. $\mathrm{DBH}$ of trees differed from $5-176 \mathrm{~cm}$, while the mean dbh in study area recorded as $80.95 \pm 43.53 \mathrm{~cm}$ (Table 1). 
Table 1. Information on A. saman recorded from Chennai metropolitan city, India.

\begin{tabular}{|c|c|}
\hline Variable & Value (Mean \pm S.D.; range) \\
\hline Density $\left(\right.$ trees $\mathrm{ha}^{-1}$ ) & $14.49 \pm 8.52 ; 0-30$ \\
\hline Basal Area $\left(m^{2} h^{-1}\right)$ & $9.61 \pm 4.95 ; 0-24.96$ \\
\hline $\mathrm{DBH}(\mathrm{cm})$ & $80.95 \pm 43.53 ; 5-176$ \\
\hline $\operatorname{AGB}\left(\mathrm{Mg} \mathrm{ha}^{-1}\right)$ & $36.8 \pm 18.9 ; 0-95.4$ \\
\hline AGB of single tree $\left(\mathrm{kg}\right.$ tree $\left.^{-1}\right)$ & $2539.1 \pm 2164.5 ; 7.48-9196.35$ \\
\hline Carbon storage $\left(\mathrm{Mg} \mathrm{ha}^{-1}\right)$ & $18.4 \pm 9.45 ; 0-47.7$ \\
\hline $\mathrm{C}$ storage of single tree $\left(\mathrm{kg}\right.$ tree $\left.^{-1}\right)$ & $1269.55 \pm 1082.25 ; 3.74-4598.18$ \\
\hline
\end{tabular}

\subsection{Aboveground Biomass}

As on March 2011, A. saman stores a sum of $6403.51 \mathrm{Mg}$ AGB in 174 ha study plots. The mean AGB of study area was $36.8 \pm 18.9 \mathrm{Mg} \mathrm{ha}^{-1}$ (range, 0 to $95.4 \mathrm{Mg} \mathrm{ha}^{-1}$ ). The mean AGB of an individual tree was recorded as $2539.1 \pm$ $2164.5 \mathrm{~kg}$ (range, 7.48 to $9196.35 \mathrm{~kg}$ ) (Table 1). DBH of tree is positively linked with AGB $\left(\mathrm{r}^{2}=0.94, \mathrm{p}<0.01\right)$. The larger is the tree the more is the sequestered biomass. The largest tree holds nearly 1200 times more AGB than the smallest one in study area. AGB storage of diameter classes varied considerably in the study area, DBH class $135.1-150.0 \mathrm{~cm}$ stored a largest quantity $(1615.25 \mathrm{Mg} ; 25.22 \%)$ followed by $120.1-135.0 \mathrm{~cm}(1236.97 \mathrm{Mg} ; 19.32 \%)$ and $105.1-120.0 \mathrm{~cm}$ (949.62 Mg; 14.83), while the least quantity was stocked by the smallest DBH class $(5-15.0 \mathrm{~cm} ; 5.67 \mathrm{Mg} ; 0.09 \%)$, (Figure 1).

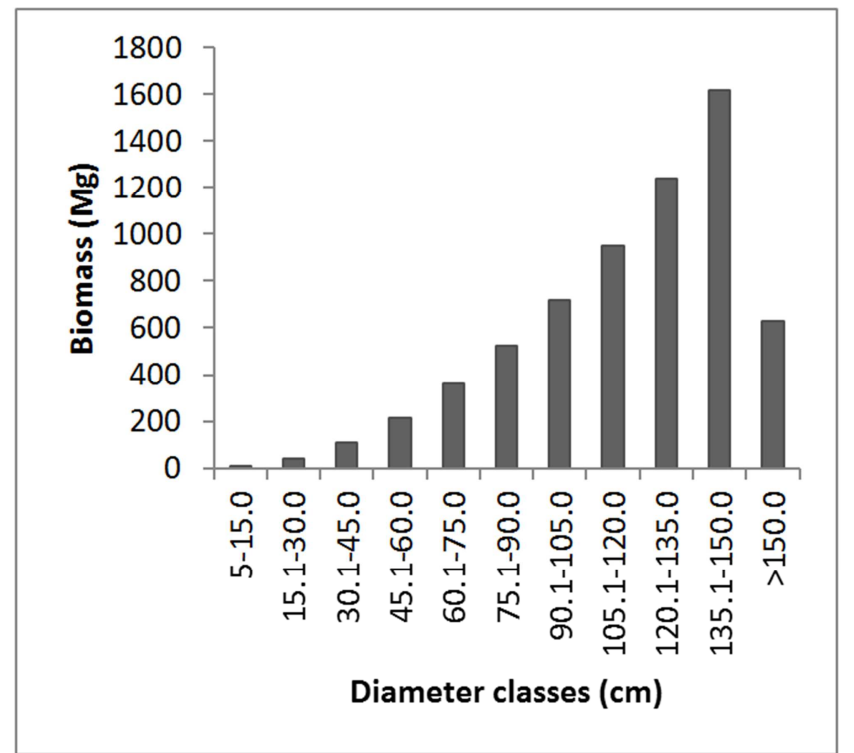

Figure 1. Aboveground biomass stored in diameter classes in Chennai metropolitan city, India.

\subsection{Carbon Storage}

In total A. saman stored $3201.76 \mathrm{Mg} \mathrm{C}$ in study area. The average $\mathrm{C}$ storage of study area was $18.9 \pm 9.45 \mathrm{Mg} \mathrm{ha}^{-1}$ (range, 0-47.7 $\mathrm{Mg} \mathrm{ha}^{-1}$ ), while each tree stored $1269.53 \pm$ $1082.25 \mathrm{~kg} \mathrm{C}$ (range, 3.74-4598.18 kg) (Table 2).
Table 2. Carbon storage and sequestration potential of tree diameter classes.

\begin{tabular}{lll}
\hline $\begin{array}{l}\text { Diameter class } \\
(\mathbf{c m})\end{array}$ & $\begin{array}{l}\text { Carbon storage } \\
\left(\mathbf{k g ~ t r e e}^{-1} \pm \text { S.D. }\right)\end{array}$ & $\begin{array}{l}\text { Carbon sequestration } \\
\left.\text { (kg tree }^{-1} \text { year }^{-1} \pm \text { S.D. }\right)\end{array}$ \\
\hline $5.0-15.0$ & $16.68 \pm 9.74$ & $4.66 \pm 1.30$ \\
$15.1-30.0$ & $83.13 \pm 30.43$ & $10.10 \pm 1.83$ \\
$30.1-45.0$ & $222.5 \pm 49.02$ & $14.37 \pm 1.40$ \\
$45.1-60.0$ & $430.94 \pm 69.34$ & $19.11 \pm 1.26$ \\
$60.1-75.0$ & $694.39 \pm 87.35$ & $22.49 \pm 1.50$ \\
$75.1-90.0$ & $1029.31 \pm 104.89$ & $27.43 \pm 1.28$ \\
$90.1-105.0$ & $1433.42 \pm 125.17$ & $29.74 \pm 1.30$ \\
$105.1-120.0$ & $1899.23 \pm 146.31$ & $31.46 \pm 1.17$ \\
$120.1-135.0$ & $2425.43 \pm 162.66$ & $30.25 \pm 4.33$ \\
$135.1-150.0$ & $3040.54 \pm 182.04$ & $23.75 \pm 2.53$ \\
$>150.0$ & $3601.93 \pm 389.85$ & $22.45 \pm 7.35$ \\
Mean & $1269.53 \pm 1082.26$ & $22.05 \pm 8.47$ \\
\hline
\end{tabular}

\subsection{Annual Horizontal Stem Growth}

On an average, each tree achieved $1.04 \pm 0.27 \mathrm{~cm}$ horizontal growth $\mathrm{yr}^{-1}$. There is a negative relationship exists between tree $\mathrm{dbh}$ and tree horizontal growth $\left(\mathrm{r}^{2}=0.87, \mathrm{p}<\right.$ $0.01)$. The smaller is the tree the larger is the annual stem horizontal growth (Table 3 ).

Table 3. Stem horizontal growth and aboveground biomass increment of Albizia saman.

\begin{tabular}{lll}
\hline $\begin{array}{l}\text { Diameter class } \\
(\mathbf{c m})\end{array}$ & $\begin{array}{l}\text { Diameter increment } \\
\left(\mathbf{c m} \text { tree }^{-1} \text { year }^{-1} \pm \text { S.D. }\right)\end{array}$ & $\begin{array}{l}\text { AGB increment } \\
\left(\text { kg tree }^{-1} \text { year }^{-1} \pm \text { S.D. }\right)\end{array}$ \\
\hline $5.0-15.0$ & $1.42 \pm 0.14$ & $9.31 \pm 2.60$ \\
$15.1-30.0$ & $1.40 \pm 0.90$ & $20.20 \pm 3.65$ \\
$30.1-45.0$ & $1.23 \pm 0.07$ & $28.74 \pm 2.79$ \\
$45.1-60.0$ & $1.18 \pm 0.04$ & $38.21 \pm 2.52$ \\
$60.1-75.0$ & $1.10 \pm 0.04$ & $44.97 \pm 2.99$ \\
$75.1-90.0$ & $1.09 \pm 0.06$ & $54.85 \pm 3.55$ \\
$90.1-105.0$ & $1.02 \pm 0.05$ & $59.48 \pm 2.59$ \\
$105.1-120.0$ & $0.95 \pm 0.07$ & $63.41 \pm 3.34$ \\
$120.1-135.0$ & $0.80 \pm 0.12$ & $60.49 \pm 8.66$ \\
$135.1-150.0$ & $0.57 \pm 0.07$ & $47.50 \pm 5.03$ \\
$>150.0$ & $0.49 \pm 0.13$ & $44.90 \pm 14.69$ \\
Mean & $1.04 \pm 0.27$ & $44.10 \pm 16.94$ \\
\hline
\end{tabular}

\subsection{Sequestration of Biomass and Carbon}

In a year A. saman population sequestered $111.23 \mathrm{Mg}$ biomass in aboveground parts (174 ha). AGB sequestration varied from 210.05 to $1639.94 \mathrm{~kg} \mathrm{ha}^{-1}$ year $^{-1}$. The mean AGB sequestration of study area was estimated as $639.24 \pm 367.99$ $\mathrm{kg} \mathrm{ha}{ }^{-1}$ year $^{-1}$. Carbon sequestration of A. saman differed from 105.03 to $819.97 \mathrm{~kg} \mathrm{ha}^{-1}$ year $^{-1}$ among study plots. The mean $\mathrm{C}$ sequestration of study area was $319.62 \pm 184.0 \mathrm{~kg}$ $\mathrm{ha}^{-1}$ year $^{-1}$. In total, the study area sequestered $55.62 \mathrm{Mg} \mathrm{C}$ year $^{-1}$.

\subsection{Absorption of $\mathrm{CO}_{2}$ for C Sequestration}

Overall, in a year A. saman absorbed $204.13 \mathrm{Mg} \mathrm{CO}_{2}$ for $\mathrm{C}$ sequestration in study area. $\mathrm{CO}_{2}$ absorption ranged from 385.46 to $3009.29 \mathrm{~kg} \mathrm{ha}^{-1} \mathrm{yr}^{-1}$. On an average, each onehectare plot absorbed $1173.0 \pm 675.28 \mathrm{~kg} \mathrm{CO}_{2}$ to sequester $\mathrm{C}$.

\subsection{Monetary Values of Carbon Storage and Sequestration}

The monetary value of $\mathrm{C}$ storage and sequestration of A. saman in study area (174 ha) is 131,272 and 2,280 US\$, 
respectively. The money value of these kind of ecosystem services of A. saman for entire CMC (17400 ha) could be estimated as 13.12 and 0.23 million US\$, respectively. On an average, the monetary values of $\mathrm{C}$ storage and sequestration of each hectare could be valued as 754 and 13.11 US\$, correspondingly.

\section{Discussion}

\subsection{Tree Density and Basal Area}

In an earlier tree diversity study conducted across different land uses of CMC A. saman constituted $6 \%$ tree community and topped in the list of important value index (IVI) among 45 species [10]. Likewise, A. saman constituted a considerable proportion of tree communities in urban forests of Bangalore and West Bengal, India [33, 34]; Bangkok, Thailand [35, 36]; Chittagong, Bangladesh [15] and USA [37].

The mean basal area recorded for A. saman $(9.61 \pm 4.95$ $\mathrm{m}^{2} \mathrm{ha}$ ) is not in agreement with previous study [23]. Earlier a study recorded $22.33 \mathrm{~m}^{2} \mathrm{BA} \mathrm{ha}^{-1}$ for A. saman. However, the previous study concentrated only on a hectare area of CMC, present study concentrated on large area i.e. 174 ha. The mean basal area recorded for species' under study is larger than the mean stand basal area (of all species) of urban forests in Ohio, USA $\left(4.8 \mathrm{~m}^{2} \mathrm{BA} \mathrm{ha}^{-1}\right)$ [38], and more or less equal to urban forests of Miami-Dade County, USA $\left(10.0 \mathrm{~m}^{2}\right.$ $\left.\mathrm{BA} \mathrm{ha}{ }^{-1}\right)$ [39]. It is apparent that the occurrence of good proportion of well-grown large trees in the CMC $(>60 \mathrm{DBH}$, $61.14 \%$ ) contributed to larger tree stand basal' areas.

\subsection{Population Structure}

Albizia saman is showing a non-expanding population structure in CMC (Figure 2). Among 11 diameter classes, nine (except smallest and largest DBH classes) had more or less similar number (230-249) of individuals. Ongoing developmental activities such as construction of buildings and bridges, widening of roads etc. are contributing to the destruction of trees. Non-expanding population structure of A. saman indicates that the individuals of all girth classes are under disturbances.

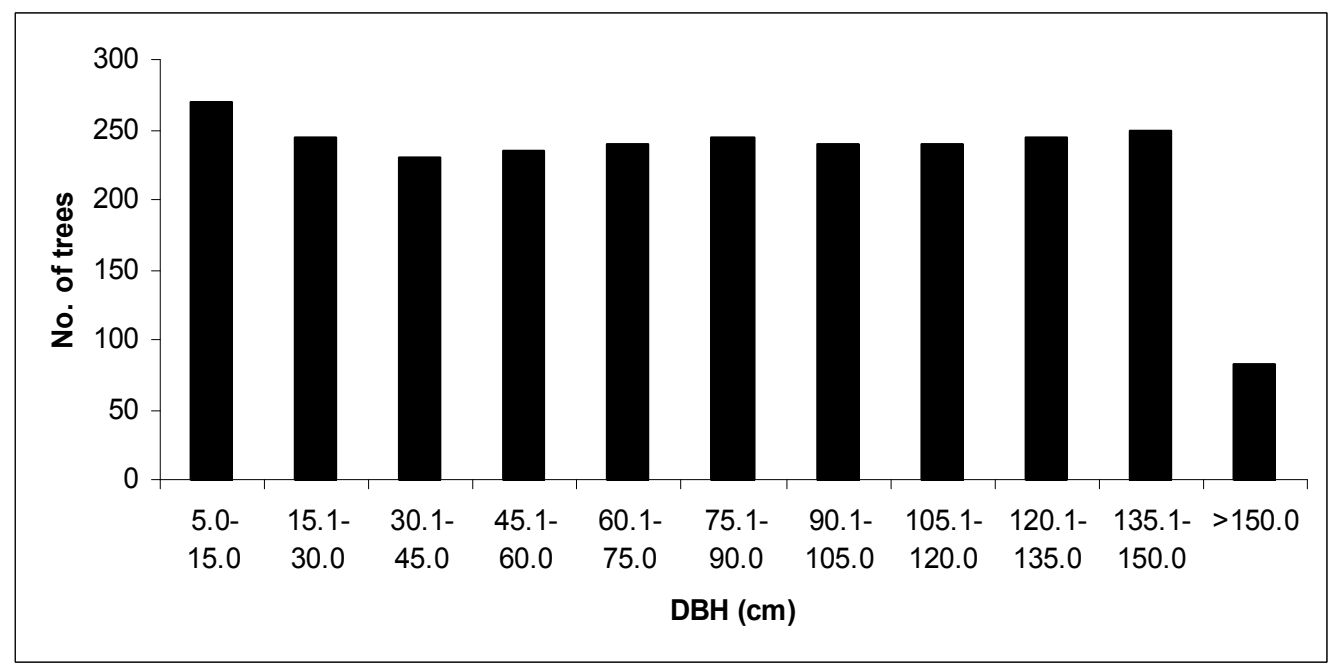

Figure 2. Population structure of $A$. saman $(\geq 5 \mathrm{~cm}$ dbh) based on diameter class frequency in Chennai metropolitan city, India

\subsection{Aboveground Biomass and Carbon Storage}

The results obtained on mean $\mathrm{AGB}$ and $\mathrm{C}$ storage of $\mathrm{A}$. saman $\left(\mathrm{AGB}=36.8 \pm 18.9 \mathrm{Mg} \mathrm{ha}^{-1} ; \mathrm{C}=18.4 \pm 9.45 \mathrm{Mg} \mathrm{ha}^{-1}\right)$ is higher than in urban forest of Tripura university campus, Northeast India $\left(\mathrm{AGB}=11.81 \mathrm{Mg} \mathrm{ha}^{-1} ; \mathrm{C}=5.91 \mathrm{Mg} \mathrm{ha}^{-1}[40]\right)$. The recorded values of current study are greater than what has been reported for all species together from Liepig, Germany (22 $\mathrm{Mg} \mathrm{ha}^{-1}, 11 \mathrm{Mg} \mathrm{ha}^{-1}$ ) [41]; Korea (23.8 $\mathrm{Mg} \mathrm{ha}^{-1}$; 11.9 $\mathrm{Mg} \mathrm{ha}^{-1}$ ) [42]; Chiayi, Taiwan (27 $\left.\mathrm{Mg} \mathrm{ha}^{-1} ; 13.5 \mathrm{Mg} \mathrm{ha}^{-1}\right)$ [43]; Beijing, China (14.82 $\mathrm{Mg} \mathrm{ha}^{-1}$; $7.42 \mathrm{Mg} \mathrm{ha}^{-1}$ ) [44]; Shenyang, China (26.34 $\mathrm{Mg} \mathrm{ha}^{-1}$; 13.17 $\mathrm{Mg} \mathrm{ha}^{-1}$ ) [32]; Los Angeles, USA (20.76 $\mathrm{Mg} \mathrm{ha}^{-1} ; 10.38 \mathrm{Mg} \mathrm{ha}^{-1}$ ) [45]; five cities of USA (5.02-15.33 $\mathrm{Mg} \mathrm{ha}^{-1}$; 10.4-30.66 $\mathrm{Mg} \mathrm{ha}^{-1}$ ) [30]; and, Oakland, USA (22 $\mathrm{Mg} \mathrm{ha}^{-1} ; 11 \mathrm{Mg} \mathrm{ha}^{-1}$ ) [46]. The population of A. saman composed of relatively larger trees (mean $\mathrm{DBH}=80.95 \mathrm{~cm}$ ) hence stored good amount of biomass and $\mathrm{C}$ in its aboveground parts. Quantitative studies should be conducted to estimate biomass and $\mathrm{C}$ storage of all tree species in Chennai city. The absence of region-specific multi-species tree allometric models is the primary lacking for these studies hence research on these lines could be valuable.

Each tree stored $1269.53 \pm 1082.25 \mathrm{~kg} \mathrm{C}$ (range, 3.74$4598.18 \mathrm{~kg}$ ) in study area. This value is higher than in Tshwane, South Africa (474.22 kg C) [47]; Beijing, China (98.87 kg C) [41]; Shenyang, China (58.51 kg C) [32]; and cities of USA $($ mean $=227.01 \mathrm{~kg} \mathrm{C}$; range $=91.81-638.95$ $\mathrm{kg} \mathrm{C)} \mathrm{[30].} \mathrm{On} \mathrm{the} \mathrm{other} \mathrm{hand,} \mathrm{the} \mathrm{present} \mathrm{study}$ concentrated only on single species' thus studies that consider all tree species in CMC are essential to confirm the dominance.

\subsection{Stem Horizontal Growth}

The findings pertaining to mean stem horizontal growth 
$(1.04 \pm 0.27 \mathrm{~cm}$ tree-1 year-1) is agreed with the result of Jo and McPherson [48] who reported $1.1 \mathrm{~cm}$ stem horizontal growth tree-1 year-1 for urban trees of USA. While the result of current study is not in line with that of deVries [49], Nowak [50] and Smith and Shifley [51] recorded 0.61, 0.90 and $0.38 \mathrm{~cm}$ horizontal stem growth tree- $1 \mathrm{yr}-1$ respectively for trees of central park, New Jersey, three USA cities, and Indiana and Illinois, USA. Fast growth nature of A. saman in CMC contributed to a high dbh growth tree- 1 yr- 1 in this study.

A negative relationship as obtained between stem horizontal growth yr-1 and diameter class is chiefly linked to the age of trees. Young trees show faster growth than larger trees. Age-related decreases in aboveground $\mathrm{C}$ sequestration were extensively recorded and reported around the world [52-54].

\subsection{Carbon Sequestration}

Carbon sequestration potential recorded for an individual tree $(22.05 \pm 8.47 \mathrm{~kg} \mathrm{yr}-1)$ in $\mathrm{CMC}$ is higher than in urban trees of Canberra, Australia (3.52 kg yr-1) [55]; Beijing, China (4.78 kg yr-1) [44]; seven cities of USA (mean=4.83, range $=3.41$ to $7.75 \mathrm{~kg} \mathrm{yr}-1)$ [30]; and Shenyang, China (5.01 $\mathrm{kg} \mathrm{yr}-1)$ [32].

The per hectare $\mathrm{C}$ sequestration potential recorded for $\mathrm{A}$. saman (319.62 $\pm 184.0 \mathrm{~kg}$ ha-1 year-1) is extremely lower than in urban forests of Pungol Eco-town, Singapore (3.61 $\mathrm{Mg}$ ha-1 yr-1) [43] and lower than in seven USA cities (458.57 kg ha-1 yr-1) [30]. Present study concentrated on single species', if all species taken in to consideration for $\mathrm{C}$ sequestration then the value may exceeds than in USA. Further studies are necessary to validate these lines. However, the per hectare $\mathrm{C}$ sequestration potential of $\mathrm{A}$. saman is relatively higher than the cumulative $\mathrm{C}$ sequestration potential (individuals belongs to all species in a hectare) of urban trees in California (300 kg ha-1 year-1), Texas (300 kg ha-1 year-1), Arizona (300 kg ha-1 year-1), Rhode Island (300 kg ha-1 year-1), North Dakota (200 kg ha-1 year-1), and Wyoming (100 kg ha-1 year-1) of USA [47, 48].

\subsection{Monetary Value of two Ecosystem Services}

The monetary value of two ecosystem services namely, C storage and sequestration of $\mathrm{A}$. saman for entire $\mathrm{CMC}$ is 13.12 and 0.23 million US\$, respectively (Table 4). The monetary value estimated in this study is higher as well as lower than in urban forests elsewhere. Stoffberg et al. [44] reported 3 million US\$ for Tshwane, South Africa; Liu and Li [32] found 13.88 million US\$ for Shenyang, China; Brack [55] calculated 20-67 million US\$ for Canberra, Australia. $\mathrm{On}$ an average the monetary value of $\mathrm{C}$ storage and sequestration of each hectare could be valued as 754 and 13.11 US\$, correspondingly.

This study calculates monetary value of just two ecosystem services. Urban trees offer many ecosystem services [see 55, 59 for details]. Valuation studies on ecosystem services of urban trees and forests are plenty in USA and other developed nations but very limited for developing countries like Brazil, Russia, India, China and South Africa. Urban forests of India can be considered as a place for ecosystem service valuation studies.

Table 4. Monetary value of two ecosystem services of Albizia saman in Chennai metropolitan city, India.

\begin{tabular}{lll}
\hline \multirow{2}{*}{ Ecosystem service } & Value (US\$) & \\
\cline { 2 - 3 } & Study area & Entire Chennai city \\
\hline Carbon storage & 131272.16 & 13127216.0 \\
Carbon sequestration (per year) & 2280.42 & 228042.0 \\
Total (as on March, 2012) & 133552.58 & 13355258.0 \\
\hline
\end{tabular}

\section{7. $\mathrm{CO}_{2}$ Emission Reduction}

In a day Chennai needs 1300 kilolitres petrol and 2000 kilolitres diesel. Use of petrol, diesel emits 3003, $5360 \mathrm{Mg}$ $\mathrm{CO}_{2}$ in to the atmosphere, respectively. In all, fossil fuel use in $\mathrm{CMC}$ releases about $8363 \mathrm{Mg} \mathrm{CO}$ into the atmosphere per day. $\mathrm{C}$ stockpile and sequestration of $\mathrm{A}$. saman is equal to $1175,204.13 \mathrm{Mg} \mathrm{CO}_{2}$, correspondingly. The average effects of tree diameter classes listed in Table 5. In total, A. saman population in $\mathrm{CMC}$ provide $\mathrm{C}$ storage and sequestration equivalent to $16.49 \%$ of a day's $\mathrm{CO}_{2}$ emissions by fossil fuels.

Table 5. Mean tree effects by tree diameter.

\begin{tabular}{|c|c|c|c|c|c|c|}
\hline \multirow{2}{*}{ DBH class (cm) } & \multicolumn{4}{|c|}{ C storage } & \multicolumn{2}{|c|}{ C sequestration } \\
\hline & (kg) & (\$) & (Petrol) $^{a}$ & (kg) & (\$) & (Petrol) $^{a}$ \\
\hline $5.0-15.0$ & 16.68 & 0.68 & 26.52 & 4.66 & 0.19 & 7.41 \\
\hline $15.1-30.0$ & 83.13 & 3.40 & 132.16 & 10.10 & 0.41 & 16.06 \\
\hline $30.1-45.0$ & 222.5 & 9.12 & 353.74 & 14.37 & 0.59 & 22.84 \\
\hline $45.1-60.0$ & 430.94 & 17.67 & 685.12 & 19.11 & 0.78 & 30.38 \\
\hline $60.1-75.0$ & 694.39 & 28.47 & 1103.96 & 22.49 & 0.92 & 35.76 \\
\hline $75.1-90.0$ & 1029.31 & 42.20 & 1636.42 & 27.43 & 1.12 & 43.61 \\
\hline $90.1-105.0$ & 1433.42 & 58.77 & 2278.88 & 29.74 & 1.22 & 47.28 \\
\hline $105.1-120.0$ & 1899.23 & 77.87 & 3019.44 & 31.46 & 1.29 & 50.02 \\
\hline $120.1-135.0$ & 2425.43 & 99.44 & 3856.01 & 30.25 & 1.24 & 48.09 \\
\hline $135.1-150.0$ & 3040.54 & 124.66 & 4833.93 & 23.75 & 0.97 & 37.76 \\
\hline$>150.0$ & 3601.93 & 147.68 & 5726.44 & 22.45 & 0.92 & 35.69 \\
\hline
\end{tabular}

${ }^{a}$ Petrol $=$ number of litres that produces emissions equivalent to tree effect 


\section{Conclusion}

Though introduced from tropical Northern South America A. saman provides a considerable quantity of ecosystem services to $\mathrm{CMC}$ through $\mathrm{C}$ storage and sequestration. This study estimated monetary values of just two ecosystem services of $A$. saman, study that concentrates on all ecosystem services is essential to assess total actual ecosystem service values.

\section{Acknowledgements}

The first author MU thanks the Department of Science and Technology, Government of India for providing the financial support through INSPIRE Fellowship (No.: IF 10051).

\section{References}

[1] Pearlmutter D, Calfapietra C, Samson R, O'Brien L, Ostoic SK, Sanesi G, and del Amo RA. 2017. The Urban ForestCultivating Green Infrastructure for People and the Environment. Springer Nature, Switzerland. pp 351.

[2] Seto KC, Guneralp B, and Hutyra LR. 2012. Global forecasts of urban expansion to 2030 and direct impacts on biodiversity and carbon pools. PNAS 109:16083-16088.

[3] Velasco E, Roth M, Norford L, and Molina LT. 2016. Does urban vegetation enhance carbon sequestration? Landscape Urban Plan 148:99-107.

[4] Nowak DJ, and Greenfield EJ. 2018. US urban forest statistics, values and projections. J For 116: 164-177.

[5] Nowak, DJ, Appleton N, Ellis A, and Greenfield E. 2017. Residential building energy conservation and avoided power plant emissions by urban and community trees in the United States. Urban For Urban Green 21:158-165.

[6] Kanniah KD, and Ho CS. 2018. Tree canopy cover and its potential to reduce $\mathrm{CO}_{2}$ in south of Peninsular Malaysia. Chem Engineer Trans 63:13-18.

[7] Lyytimaki J. 2017. Disservices of urban trees. Chapter 12, p. 164-176, in Routledge handbook of urban forestry, Ferrini, F., C.C. Konijnendijk, and A. Fini (eds.). Routledge, New York.

[8] Dobbs, C., M.J. Martinez-Harms, and D. Kendal. 2017. Ecosystem services. Chapter 4, p. 51-64, in Routledge handbook of urban forestry, Ferrini, F., C.C. Konijnendijk, and A. Fini (eds.). Routledge, New York.

[9] Amoatey P, Sulaiman H, Kwarteng A, and Al-Reasi HA. 2018 Above-ground carbon dynamics in different arid urban green spaces. Environ Earth Sci 77:431.

[10] Nagendra H, and Gopal D. 2011. Tree diversity, distribution, history and change in urban parks: studies in Bangalore, India. Urban Ecosyst 14:211-223.

[11] Zipperer WC. 2002. Species composition and structure of regenerated and remnant forest patches within an urban landscape. Urban Ecosyst 6:271-290.

[12] McKinney ML. 2006. Urbanization as a major cause of biotic homogenization. Biol Conserv 127:247-260.
[13] Pickett STA, Cadenasso ML, Grove JM, Groffman PM, Band LE, Boone CG, Burch WR, Grimmond, CSB, Hom J, Jenkins JC, Law NL, Nilon CH, Pouyat RV, Szlavecz K, Warren PS, and Wilson MA. 2008. Beyond urban legends: an emerging frame work of urban ecology, as illustrated by the Baltimore Ecosystem Study. Bioscience 58:139-150.

[14] Species Profiles for Pacific Island Agroforestry. 2015. [http://www.traditionaltree.org.].

[15] Miah D, Ahmed R, and Uddin MB. 2003. Biomass fuel use by the rural households in Chittagong region, Bangladesh. Biomass Bioenerg 24:277-283.

[16] Agroforestree Database: a tree reference and selection guide version 4.0.

[http://www.worldagroforestry.org/treedb2/AFTPDFS/Albizia saman_pdf]

[17] Hong Y, and Bhatnagar S. 2007. Tropical Tree Legumes. In: Biotechnology in Agriculture and Forestry: 2007; SpringerVerlag, Berlin, Heidelberg, 407-431.

[18] Sotelo A, Contreras E, and Flores S. 1995. Nutritional value and content of antinutritional compounds and toxics in ten wild legumes of Yucatan Peninsula. Plant Food Huma Nutr 47:115-123.

[19] Macedo MO, Resende AS, Garcia PC, Boddey RM, Jantalia CP, Urquiga S, Campello EFC, and Franco AA. 2008. Changes in soil $\mathrm{C}$ and $\mathrm{N}$ stocks and nutrient dynamics 13 years after recovery of degraded land using leguminous nitrogen-fixing trees. Forest Ecol Manag 255:1516-1524.

[20] Praveen RN, Viswanathan S, Devi JR, Nayak V, Swetha VC, Archana BR, Parthasarathy N, and Rajkumar J. 2008. Preliminary Phytochemical screening and antimicrobial activity of Samanea saman. J Med Plant Res 2:268-270.

[21] Ukoha PO, Cemaluk EAC, Nnamdi OL, and Madus EP. 2011. Tannins and other Phytochemical of the Samanaea saman pods and their antimicrobial activities. Afr J Pure Appl Chem 5:237-244.

[22] Mayuranathan PV. 1929. The flowering plants of Madras city and its immediate neighbourhood. In: Bulletin of the Madras government museum, Madras Government Press, Madras, India.

[23] Muthulingam U, and Thangavel S. 2012. Density, diversity and species richness of woody plants in urban green spaces: A case study in Chennai metropolitan city, India. Urban For Urban Gree 11:451-458.

[24] Population Census India, 2011. [http://www.census 2011.co.in/census/district/21-chennai.html.]

[25] Climate and Weather of Chennai Metropolitan. [http://www.chennai district/tn.nic.in.]

[26] Udayakumar M. 2012. Ecological studies on selected sacred groves of southern Coromandel coast, Peninsular India. Annual Report 2011-2012, submitted to Department of Science and Technology, Government of India, New Delhi, $p$ 20.

[27] Udayakumar M: 2011. Ecological studies on selected sacred groves of southern Coromandel coast, Peninsular India. Annual Report 2010-2011, submitted to Department of Science and Technology, Government of India, New Delhi, $p$ 10 . 
[28] Miller D. 1984. Reducing Transformation Bias in Curve Fitting. Am Stat 38:124-126.

[29] Sprugel DG. 1983. Correcting for bias in log-transformed allometric equations. Ecology 64:209-210.

[30] Nowak DJ, and Crane DE. 2002. Carbon storage and sequestration by urban trees in the USA. Environ Pollut 2002, 116(3), 381-389.

[31] McPherson EG, and Simpson JR. 1999. Carbon dioxide reduction through urban forestry: guidelines for professional and volunteer tree planters. General Technical Report PSW171. USDA Forest Service, Pacific Southwest Research Station, Albany, CA.

[32] Liu S, and Li X. 2012. Carbon storage and sequestration by urban forests in Shenyang, China. Urban For Urban Gree 11:121-128.

[33] Nagendra H, and Gopal D. 2010. Street trees in Bangalore: Density, diversity, composition and distribution. Urban For Urban Gree 9:129-137.

[34] Thakur S, Agarwal SK, Pramanick P, Mitra S, Biswas P, and Mitra A. 2016. Green patches as carbon reservoir: A case study from Dhruba Chand Halder College, West Bengal. Int J Advance Res Bio Sci 3:160-164.

[35] Thaiutsa B, Puangchit L, Kjelgren R, and Arunpraparut W. 2008. Urban green space, street tree and heritage large tree assessment in Bangkok, Thailand. Urban For Urban Gree 7:219-229.

[36] Fujimoto M, Puangchit L, Sugawara F, Sripraram D, Jiamjeerakul W, and Kato H. 2016. Carbon sequestration estimation of urban trees in parks and streets of Bangkok metropolitan, Thailand. Thai J For 35:35-41.

[37] Borchert R, Robertson K, Schwartz MD, and Williams-Liners G. 2005. Phenology of temperate trees in tropical climates. Int J Biometeorol 2005, 50: 57-65.

[38] Porter EE, Forschner BR, and Blair RB. 2001. Woody vegetation and canopy fragmentation along a forest-to-urban gradient. Urban Ecosyst 5:131-151.

[39] Zhao M, Escobedo FJ, and Staudhammer C. 2010. Spatial patterns of a subtropical, coastal urban forest: Implications for land tenure, hurricanes, and invasives. Urban For Urban Gree 9:205-214.

[40] Deb D, Deb S, Debbarma J, and Datta BK. 2016. Tree species richness and carbon stock in Tripura University campus, Northeast India. J Biodivers Manage Forestry 5:4 (DOI: $10.4172 / 2327-4417.1000167)$

[41] Strohbach MW, and Haase D. 2012. Above-ground carbon storage by urban trees of Leipig, Germany: Analysis of patterns in a European city. Landscape Urban Plan 104:95104.

[42] Jo HK. 2002. Impacts of urban green space on offsetting carbon emissions from middle Korea. J Environ Manage 64:115-126.

[43] Huang HH, Huang HW, and Chang SH. 2009. The study of ecological benefits of Chiayi city, In: Proceedings REAL CORP, Tagungsband, Taiwan, 535-540.
[44] Yang J, McBride J, Zhou J, and Sun Z. 2005. The urban forest in Beijing and its role in air pollution reduction. Urban For Urban Gree 3:65-78.

[45] Nowak DJ, Hoehn RE, Crane DE, Weller R, and Davila A. 2011. Assessing Urban Forest Effects and Values: Los Angeles' Urban Forest. Resource Bulletin NRS-47. United States Department of Agriculture. USDA Forest Service, Northern Research Station, USA, 35 pp.

[46] Nowak DJ. 1993. Historical vegetation change in Oakland and its implications for urban forest management. J Arbor 19:313319 .

[47] Stoffberg GH, van-Rooyen MW, van-der Linde MJ, and Groeneveld HT. 2010. Carbon sequestration estimates of indigenous street trees in the City of Tshwane, South Africa. Urban For Urban Gree 9:9-14.

[48] Jo HK, and McPherson EG. 1995. Carbon storage and flux in urban residential greenspace. J Environ Manage 45:109-133.

[49] de Vries RE. 1987. A preliminary investigation of the growth and longevity of trees in Central Park. MS thesis, Rutgers University, New Brunswick, New Jersey.

[50] Nowak DJ. 1994. Urban Forest structure: The state of Chicago's urban forest. In: Chicago's urban forest ecosystem: Results of the Chicago Urban Forest Climate Project. General Technical Report, NE-186. U.S. Department of Agriculture, Forest Service, Radnor, PA, 3-18.

[51] Smith WB, and Shifley SR. 1984. Diameter Growth, Survival, and Volume Estimates for Trees in Indiana and Illinois. Research Paper NC-257. U.S. Department of Agriculture, Forest Service, North Central Forest Experiment Station, St. Paul, MN, p 10.

[52] Pregitzer KS, and Euskirchen ES. 2004. Carbon cycling and storage in world forests: biome patterns related to forest age. Global Change Biol 10:2052-2077.

[53] Bradford JB, and Kastendick DN. 2010. Age-related patterns of forest complexity and carbon storage in pine and aspenbirch ecosystems of northern Minnesota, USA. Can J Forest Res, 40:401-409.

[54] D'Amato AW, Bradford JB, Fraver S, and Palik BJ. 2011. Forest management for mitigation and adaptation to climate change: insights from long-term silviculture experiments. Forest Ecol Manag 2011, 262:1-13.

[55] Brack CL. 2002. Pollution mitigation and carbon sequestration in an urban forest. Environ Pollut 116:S 195-200.

[56] Goh JCJ. 2017. Carbon accounting in local-scale land use and land cover change. Consilience: J Sustain Develop 17:46-74.

[57] Dwyer JF, McPherson EG, Schroeder HW, and Rowntree RA. 1992. Assessing the benefits and costs of the urban forests. J Arbor 18:227-234.

[58] Nowak DJ, Noble MH, Sisinni SM, and Dwyer JF. 2001. Assessing the US urban forest resource. J Forest, 99:37-42.

[59] Bolund P, and Hunhammar S. 1999. Ecosystem services in urban areas. Ecol Econ 1999, 29(1):293-301. 